\title{
Primary pulmonary hypertension and human immunodeficiency virus infection
}

\author{
J Conly MD, R Hilsden MD, H Deneer PhD, I Etches MD, T Moyana MD
}

\begin{abstract}
J Conly, R Hilsden, H Deneer, I Etches, T Moyana. Primary pulmonary hypertension and human immunodeficiency virus infection. Can J Infect Dis 1997;8(5):290-293. This report details the case of a 42-year-old homosexual Caucasian male with infection due to human immunodeficiency virus type 1 (HIV-1) who presented with a four-month history of progressive dyspnea and was found to have clinical and hemodynamic evidence of severe pulmonary hypertension. He had had no opportunistic infections, and had a Thelper lymphocyte count of $200 \times 10^{6} / \mathrm{L}$. Extensive clinical laboratory and radiological evaluations revealed no underlying cause. Microscopic examination of postmortem lung tissue revealed findings consistent with grade $\mathrm{V}$ pulmonary hypertension. Electron microscopic analysis and polyermase chain reaction detection of HIV-DNA from dissected pulmonary arterioles failed to provide any supportive evidence to suggest productive infection of the pulmonary arteriolar endothelial cells by HIV-1. Although HIV-1 likely plays a role in the pathogenesis of primary pulmonary hypertension, evidence for direct infection of pulmonary vessel endothelium was lacking in this case. The pathogenesis of primary pulmonary hypertension associated with HIV remains obscure.
\end{abstract}

Key Words: AIDS, Pulmonary hypertension

\section{Hypertension pulmonaire primaire et infection au virus de l'immunodéficience humaine}

RÉSUMÉ : Le présent rapport présente les caractéristiques d'un patient homosexuel de race blanche âgé de 42 ans atteint d'une infection au virus de l'immunodéficience humaine de type 1 (VIH 1) qui s'est présenté pour dyspnée progressive remontant à quatre mois et qui s'est révélé atteint de signes cliniques hémodynamiques d'hypertension pulmonaire grave. Il ne souffrait d'aucune infection opportuniste et présentait une numération de lymphocytes T à $200 \mathrm{x}$ $10^{6} / \mathrm{L}$. Les analyses de laboratoire et les examens radiologiques approfondis n'ont permis d'identifier aucune cause sous-jacente. L'examen microscopique des tissus pulmonaires à l'autopsie a révélé des signes d'hypertension pulmonaire de classe 5. L'analyse à la microscopie électronique et au dépistage de l'ADN du VIH par amplification génique à partir d'artérioles pulmonaires disséquées n'ont pu fournir la preuve d'une infection productive des cellules endothéliales artériolaires pulmonaires par le VIH 1. Bien que le VIH 1 joue sans doute un rôle dans la pathogenèse de l'hypertension pulmonaire primaire, aucun signe d'une infection directe de l'endothélium vasculaire pulmonaire n'a pu être confirmé dans ce cas. La pathogenèse de l'hypertension pulmonaire primaire associée au VIH reste méconnue.

$\mathrm{S}$ everal cardiopulmonary complications have been reported in association with infection secondary to human immunodeficiency virus (HIV), including dilated cardiomyopathy, pericardial effusions, pleural effusions and mycocarditis

(1-4). Recent reports have described an association between primary pulmonary hypertension and HIV infection $(5,6)$. The development of pulmonary hypertension and its association with HIV infection have been obscured by potential secondary

Departments of Medicine, Microbiology and Pathology, University of Saskatchewan, Saskatoon, Saskatchewan

Correspondence: Dr John Conly, The Toronto Hospital, NU 13-118, 200 Elizabeth Street, Toronto, Ontario M5G 2C4. Telephone

416-340-4858, fax 416-340-5047, e-mail jconly@torhosp.toronto.on.ca

Received for publication July 4, 1996. Accepted December 4, 1996 
causes of pulmonary hypertension including intravenous drug use and other pulmonary disease. We report our experience with an HIV-positive patient with idiopathic (primary) pulmonary hypertension and describe the clinical, pathological and molecular investigations that were performed to elucidate the etiology of the hypertension. To our knowledge this is the first reported patient in Canada in whom this association has been observed.

\section{CASE PRESENTATION}

Clinical evaluation: A 42-year-old homosexual HIV-positive male was admitted to hospital for investigation of a fourmonth history of progressive dyspnea. Initially, dyspnea had been on exertion only but had progressed to dyspnea after walking only a few steps. He was diagnosed as HIV-positive three years previously and had suffered from oral thrush, oral hairy leukoplakia and mild thrombocytopenia, but had not had any AIDS-defining illnesses. He had been treated with zidovudine for three months, dextran sulphate for 11 months and didanosine for only two weeks before admission to hospital. His past medical history was positive for recurrent depressive episodes requiring tricyclic antidepressants and an episode of transient left hemiparesis 18 months before presentation. Extensive investigations including Doppler examination of the great vessels, computed tomographic scan of the head, echocardiography and laboratory evaluation for evidence of a hypercoaguable state were unremarkable. The etiology of the hemiparesis that subsequently resolved was unclear but was thought to be a manifestation of an HIV encephalopathy. He had not used intravenous drugs in the past but had a 32 pack-year history of smoking.

On examination, the patient looked unwell, was dehydrated and was tachypneic at rest, with a respiratory rate of 26 breaths/min. Temperature was $35.5^{\circ} \mathrm{C}$, pulse was 100 beats/min and regular, and blood pressure was 103/84 mmHg. Examination of the respiratory system was unremarkable aside from tachypnea. The patient's neck veins were not detectable above the sternal angle when the patient was lying quietly, but with minimal exertion increased to over $10 \mathrm{~cm}$ above the sternal angle. There was a moderate left parastemal heave, an accentuated second heart sound and a soft midsystolic murmur at the left stemal border. Moderate ankle edema was present, and the liver was enlarged and tender.

Laboratory evaluations revealed hemoglobin of $106 \mathrm{~g} / \mathrm{L}$, a nucleated blood count $4.0 \times 10^{9} / \mathrm{L}$ and a platelet count $16 \times 10^{9} / \mathrm{L}$, which had decreased from $75 \times 10^{9} / \mathrm{L}$ from six months previously. An antiphospholipid antibodies screen was negative. Recent T helper count was $210 \times 10^{6} / \mathrm{L}$. Chest radiograph revealed clear lung fields but a moderately enlarged cardiac silhouette. A two-dimensional echocardiogram revealed severe pulmonary hypertension with an estimated pulmonary artery pressure of $99 \mathrm{mmHg}$. The right ventricle was severely dilated and hypokinetic with severe tricuspid regurgitation and pulmonic regurgitation. A small-moderate circumferential pericardial effusion (300 to $400 \mathrm{~mL}$ ) was also present. Perfusion lung scan revealed uniform distribution throughout both lungs and no evidence of acute pulmonary

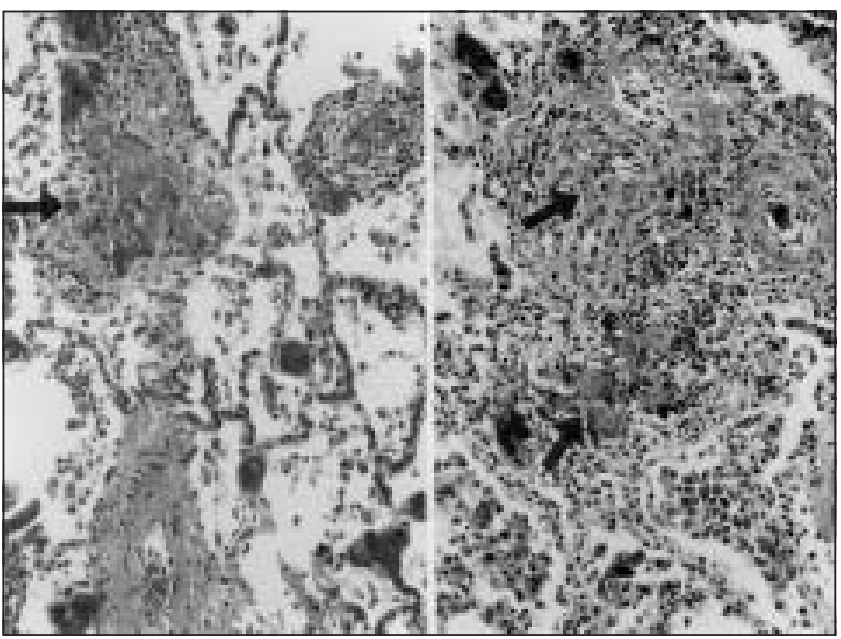

Figure 1) Left Small pulmonary arteries showing intimal fibrosis, prominent endothelial cells and an area of fibrinoid necrosis (arrow). Right Severe endothelial proliferation with plexiform lesions (arrows)

thromboembolic disease. Pulmonary angiography was not performed.

Medical records revealed the patient had been completely evaluated on two separate occasions within the previous four months for his complaint of progressive dyspnea. A chest radiograph, two-dimensional echocardiogram, ventilation perfusion lung scan, complete pulmonary function studies and an exercise thallium scan were completed during the preceding two to four months and did not reveal any findings suggestive of pulmonary hypertension. Following initial investigations at the time of this admission, the patient declined any active treatment and subsequently died.

Pathology: Postmortem examination revealed dilation of the superior and inferior vena cava and right atrium, and evidence of right ventricular hypertrophy with an average right ventricle thickness of $0.8 \mathrm{~cm}$. The wall of the main pulmonary artery was thickened, and there were yellowish intimal plaques on the intimal surface. The lungs were firm and rubbery in consistency, and there were bilateral pleural effusions, a moderate pericardial effusion, hepatosplenomegaly, ascites and moderate pulmonary congestion. There was no macroscopic evidence of recent or organizing thrombi in any of the segments of the pulmonary artery. Microscopic examination of formalin-fixed paraffin embedded sections of lung tissue (Figure 1) revealed marked medial hypertrophy of small muscular pulmonary arteries with cellular intimal proliferation and concentric fibrosis of medium-sized muscular arteries. These changes were present in all the arteries but with varying degrees of severity in individual vessels. Fibrinoid necrosis of moderate degree was noted in small muscular arteries throughout the lungs, and occasional recent and organizing thrombi were present. In the right upper lobe, well developed angiomatoid lesions were seen. No evidence of vasculitis was found. The findings were most compatible with grade $\mathrm{V}$ pulmonary hypertension of the Heath and Edwards classification (7).

Molecular studies: To assess the possibility that a productive HIV-1 infection of the pulmonary vascular endothelial cells led to alterations that were responsible for the development of pul- 
monary hypertension in this patient, electron microscopic analysis of the endothelial lining from small pulmonary arterioles, which were carefully dissected from the pulmonary vasculature, was performed. Other than nonspecific enlargement of the endothelial cells, no other morphological findings were noted.

The small pulmonary arterioles that were dissected from the postmortem pulmonary vasculature were tested to determine whether any HIV-1 amplified DNA product could be detected. The Repliprimer System (Dupont Biotechnology Systems and Nen Research Products, Dupont Canada Inc) (primers of 5 CCAGGAAGATGGAAACCAAA and 3 GTCAATGGCCATTGTTTAAC) for detection of a highly conserved 262 basepairs HIV-1 amplified DNA product was used. Samples tested included a negative control containing no DNA added to the reaction, a positive control containing known amounts of target sequence, a positive tissue control that had been 'spiked' with HIV-1 DNA and the arterioler tissue samples from this patient. The reaction mixture was electrophoresed on a $1.5 \times 20 \mathrm{~cm}$ agarose gel at $200 \mathrm{~V}$ for $2 \mathrm{~h}$ in a Tris-borate running buffer according to the manufacturer's instructions. The gel was stained with ethidium bromide, and the product of interest visualized on an ultraviolet transilluminator. Although the two controls were positive in this case, the samples from the patient containing pulmonary vascular endothelial tissue were negative.

\section{DISCUSSION}

The clinical and pathological findings in our patient were compatible with severe pulmonary hypertension that only manifested clinically within the final months of life. Despite extensive investigation, no secondary cause for the pulmonary hypertension could be found. There were no features suggestive of chronic lung disease, no evidence of collagen vascular disease, no evidence for antiphospholipid antibodies and no history of ingestion of anorectic agents. As well, the patient had not used intravenous drugs. Furthermore, there was no evidence to suggest cirrhosis or portal hypertension, which has also been associated with pulmonary hypertension. Gross pathological examination and microscopic findings of a medial hypertrophy of small muscular arteries and concentric fibrosis of medium-sized muscular arteries, showing only occasional recent or organizing thrombi on a generalized basis, provided very strong evidence against recent or recurrent thromboembolic disease causing the pulmonary hypertension in this case. Our case easily meets the definition of primary pulmonary hypertension as delineated by the World Health Organization (8).

The pathogenesis of HIV-associated primary pulmonary hypertension remains obscure. Of the 23 cases $(5,6,8-14)$ described in the literature all cases have been male, which is unusual given the usual female preponderance in non-HIV associated primary pulmonary hypertension. There seems to be no predilection for the development of disease according to the degree of immunodeficiency. Our patient had a T helper lymphocyte count above $200 \times 10^{6} / \mathrm{L}$, and in the other reported cases where values were available four patients had counts below $200 \times 10^{6} / \mathrm{L}$ and seven others had counts above
$225 \times 10^{6} / \mathrm{L}$. Vasculitis has not been noted histologically in any of the cases, and no signs of inflammatory vessel changes have been noted. The presence of antiphospholipid antibodies has been described in HIV infection and may be associated with an increase in thromboembolic phenomena but none were found in our case.

Given that endothelial cells may be targets for HIV infection in vivo $(15,16)$, the finding of some CD4 receptors on the surface of endothelial cells (17) and the impairment of endothelial cell functions in HIV-1 infected patients with increased plasma levels of von Willebrand factor and plasminogen activator inhibitor (18), we sought direct evidence of the pulmonary endothelial cells using electron microscopy and polymerase chain reaction (PCR) amplification of a conserved fragment of the HIV-1 genome. Although we were unable to demonstrate any findings suggestive of HIV infection in the arterioler samples from our patient, we acknowledge the limitations of the procedures employed. It always remains possible that with more extensive sampling or with the use of additional procedures, such as in situ hybridization using HIV-1 DNA specific probes, the ability to detect findings may be enhanced. The use of hybridization techniques in addition to PCR detection might increase the sensitivity of detection. Another group of investigators (14) attempted to localize HIV-1 infection to the pulmonary vascular endothelium in three patients using immunohistochemistry, in situ hybridization using a nick translated and biotinylated HIV-1 DNA probe, and PCR detection but were unable to detect any evidence of direct HIV infection.

Possible explanations for the development of primary pulmonary hypertension in association with HIV infection may be immunological perturbations of the endothelial cells (19) or the production of growth factors either directly related to the virus or mediated through T cells which cause endothelial cell perturbations $(20,21)$. A regulatory gene from HIV-1 that triggers growth of Kaposi's sarcoma and a growth factor from HIV-1 infected T cells that stimulates the growth of human endothelial cells in vitro have been described.

Whatever the mechanism, it is likely that further cases of pulmonary hypertension in association with HIV will be seen. The occurrence of dyspnea of no obvious cause after routine investigations in a patient with HIV infection should prompt consideration of primary pulmonary hypertension as an explanation regardless of whether there is any clinical evidence of right ventricular dysfunction.

\section{REFERENCES}

1. Murray JF, Felton CP, Garay SM, et al. Pulmonary complications of the acquired immunodeficiency syndrome. N Engl J Med 1984;310:1682-8.

2. Acierno LJ. Cardiac complications in acquired immunodeficiency syndrome (AIDS): A review. J Am Coll Cardiol 1989;13:1144-54.

3. Himelmann RB, Chung WS, Chernoff DC, Schiller NB, Hollander H. Cardiac manifestations of human immunodeficiency virus infection: A two-dimensional echocardiographic study. J Am Coll Cardiol 1989;13:1030-6.

4. Anderson DW, Virmani R, Reilly JM, et al. Prevalent myocarditis at necropsy in the acquired immunodeficiency syndrome. J Am Coll Cardiol 1988;11:792-9.

5. Coplan NL, Shimony RY, Ioachim HL, et al. Primary pulmonary hypertension associated with human immunodeficiency viral infection. Am J Med 1990;89:96-9. 
6. Speich R, Jenni R, Opravil M, Pfab M, Russi EW. Primary pulmonary hypertension in HIV infection. Chest 1991;100:1268-71.

7. Heath D, Edwards JE. The pathology of hypertensive pulmonary vascular disease. A description of six grades of changes in the pulmonary arteries with special reference to congenital cardiac septal defects. Circulation 1958;18:533.

8. Hatano S, Strasser T, eds. Primary Pulmonary Hypertension: Report on a WHO Meeting. Geneva: World Health Organization, 1975.

9. Goldsmith GH, Baily RG, Brettier DB, et al. Primary pulmonary hypertension in patients with classic hemophilia. Ann Intern Med 1988;108:797-9.

10. Bray GL, Martin GR, Chandra R. Idiopathic pulmonary hypertension, hemophilia A and infection with human immunodeficiency virus (HIV). Ann Intern Med 1989;111:689-90.

11. Legoux B, Piette AM, Bouchet PF, Landau JF, Gepner P, Chapman AM. Pulmonary hypertension and human immunodeficiency virus infection. Am J Med 1990;89:122.

12. Aarons EJ, Nye FJ. Primary pulmonary hypertension and HIV infection. AIDS 1991;5:1276-7.

13. Himelman RB, Dohramann M, Goodman P, et al. Severe pulmonary hypertension and corpulmonale in the acquired immunodeficiency syndrome. Am J Cardiol 1989;64:1396-8.

14. Mette SA, Palevsky HI, Pietra GG, et al. Primary pulmonary hypertension in association with human immunodeficiency virus infection. A possible viral etiology for some forms of hypertensive pulmonary arteriopathy. Am Review Respir Dis 1992;145:1196-200.

15. Wiley CA, Schrier D, Nelson JA, Lampert PW, Oldstone MB. Cellular localization of human immunodeficiency virus infection within the brains of acquired immune deficiency syndrome patients. Proc Natl Acad Sci USA 1986;83:7089-93.

16. Pomerantz RJ, Kuritzkes DR, de la Monte SM, et al. Infection of the retina by human immunodeficiency virus type $1 . \mathrm{N}$ Engl J Med 1987;317:1643-7.

17. Drouct L, Scrobohaci ML, Janier M, Baudin B. Endothelial cells: Target for the HIV 1 virus? Nouv Rev Fr Hematol 1990;32:103-6.

18. Teitel JM, Shore A, Read SE, Schiavone A. Immune function of vascular endothelial cells is impaired by HIV. J Infect Dis 1989;160:551-2

19. Lafeuillade A, Alessi MC, Poizot-Martin I, et al. Endothelial cell dysfunction in HIV infection. J Acquir Immune Defic Syndr 1992;5:127-31.

20. Vogel J, Hinrichs S, Reynolds R, Luciw P, Jay G. The HIV gene induces dermal lesions resembling Kaposi's sarcoma in transgenic mice. Nature 1988;335:606-11.

21. Nakamura S, Salahuddin SZ, Biberfeld P, et al. Kaposi's sarcoma cells: Long-term culture with growth factor from retrovirus-infected CD4+ T cells. Science 1988;242:426-9.

\section{CLINICAL VIGNETTE}

Continued from page 264

\section{DIAGNOSIS}

The pathologist reported fragments of spindled cells without significant pleomorphism of mitotic activity and the absence of granulomata (Figure 1). Specific stains for actin, myosin and desmin supported the cell of origin as smooth muscle and the diagnosis of a leiomyoma. No intervention was undertaken, and the lesion was monitored with serial ultrasounds. An ultrasound performed three months after the initial diagnosis revealed no change in one lesion and slow growth of the second lesion to $17 \mathrm{~mm}$. Blood was positive for EBV PCR at that time. His antiretroviral regimen was changed to lamivudine, stavudine and ritonavir, resulting in improvement of his gastrointestinal symptoms, significant weight gain, modest improvement of his CD4 count to $247 / \mathrm{mm}^{3}$ and decline of HIV viral load to less than $2.2 \log _{10}$ HIV RNA copies/mL of plasma.

\section{DISCUSSION}

The incidence of neoplasms is increased in all individuals with HIV infection, although this incidence is lower in children than adults. Arico et al (1) reported a $2 \%$ to $8 \%$ prevalence of malignancies in a series of children perinatally affected with HIV. The most common neoplasm in pediatric HIV and other immunodeficiency states is lymphoma (2).

Leiomyomata and leiomyosarcomata are very rare in normal children, with an estimated incidence of the latter of less than 1.6 per 10 million children (3). Conversely, children with HIV have an unusually high incidence of these benign and malignant tumours of smooth muscle. These tumours most commonly are found in the lungs, spleen and gastrointestinal tract (4).

EBV has been implicated as an etiological agent in leiomyomata and leiomyosarcomata in children with HIV. McClain et al (5) compared tissues from two leiomyomata and five leiomyosarcomata from five children and one young adult with HIV against samples of similar lesions from HIVnegative children. EBV genomes were present in all samples from HIV-infected individuals by in situ hybridization and EBV PCR, while EBV DNA was absent from specimens from HIV-negative patients. The therapy for malignant lesions includes surgery, chemotherapy, interferon-alpha and radiation therapy, although despite therapy these lesions tend to recur.

Tumours of smooth muscle should be included in the differential diagnosis of space occupying lesions of the liver, gut, spleen and lung in pediatric patients with HIV infection.

\section{REFERENCES}

1. Arico M, Castili D, D'argenio PD, et al. Malignancies in children with human immunodeficiency virus type 1 infection. Cancer $1991 ; 68: 2373$

2. Filipovich A. Lymphoproliferative disorders associated with immunodeficiency. In: Magrath IT, ed. The Non-Hodgkin's Lymphomas. London: Edward Arnold, 1990;135.

3. Chadwick EG, Connor EJ, Hanson CG, et al. Tumours of smooth-muscle origin in HIV-infected children. JAMA 1990;263:3182-4.

4. McClain KL, Joshi VV, Murphy SB. Cancers in children with HIV infection. Hematol Oncol Clin North Am 1996;10:5:1189-201.

5. McClain KL, Leach CT, Jenson HB, et al. Association of Epstein-Barr virus with leiomyosarcomas in young people with AIDS. N Engl J Med 1995;332:12-8. 


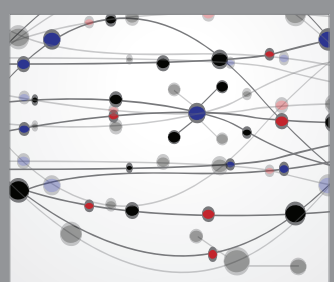

The Scientific World Journal
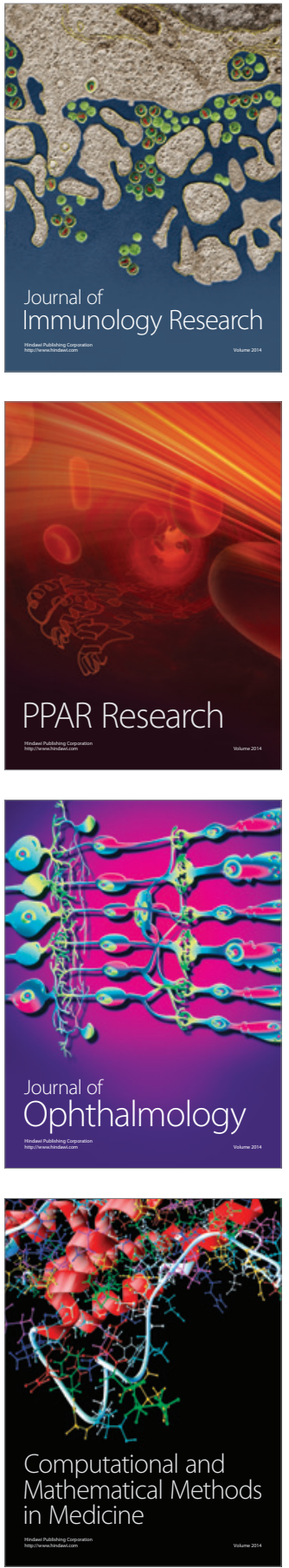

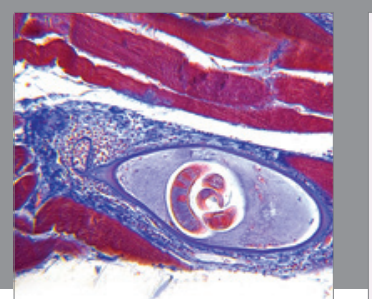

Gastroenterology Research and Practice

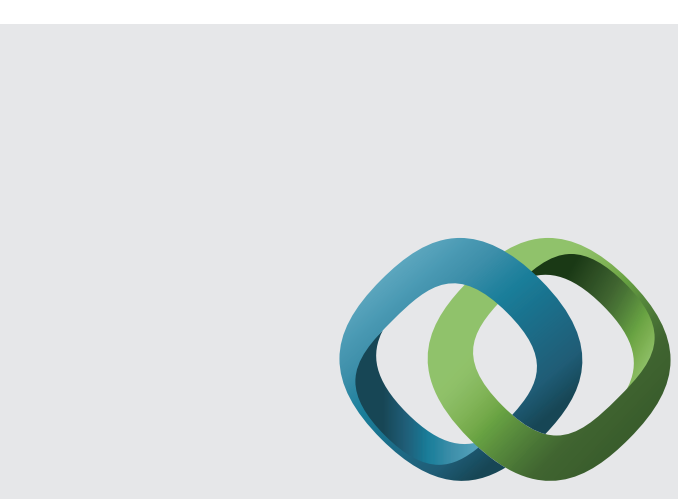

\section{Hindawi}

Submit your manuscripts at

http://www.hindawi.com
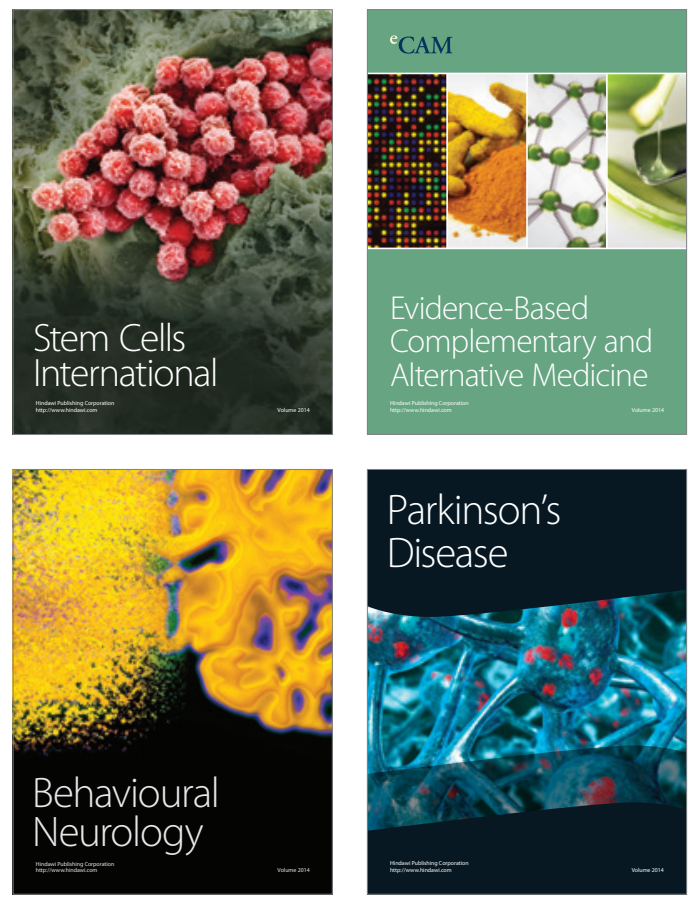
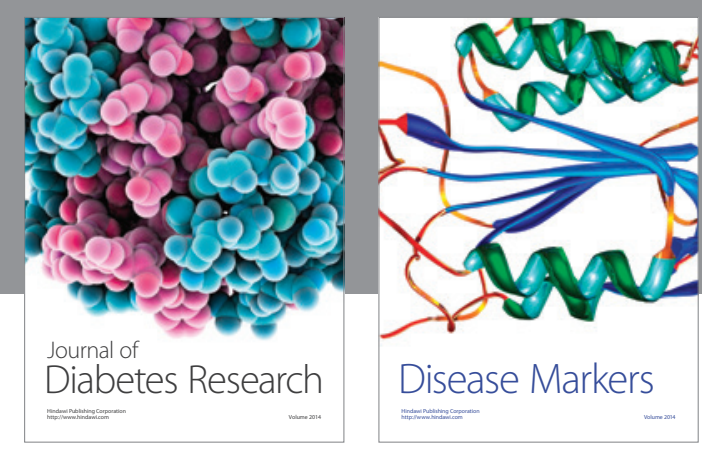

Disease Markers
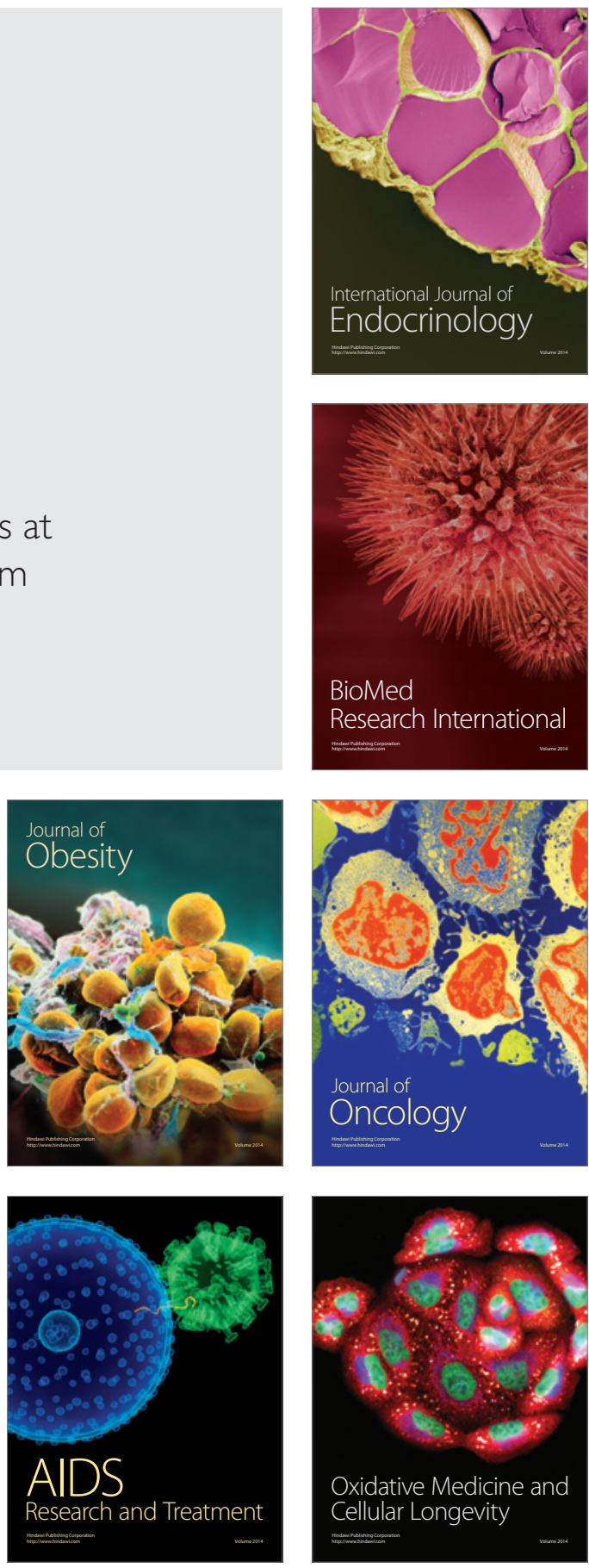